\title{
Optimized visual stimuli for BCI with hessenberg decomposition based extreme learning machine
}

\author{
Apdullah Yayık * Yakup Kutlu§ Gökhan Altan ${ }^{\ddagger}$
}

The authors have withdrawn this manuscript as it was posted in error. Therefore, the authors do not wish for this work to be cited as reference for the project. Please contact the corresponding author if you have any questions.

\footnotetext{
*National Defense University, ayayik@kho.edu.tr

†İskenderun Technical University, Department of Computer Engineering

$\ddagger$ İskenderun Technical University, Department of Computer Engineering
} 